\title{
DEVELOPMENT OF A WIRELESS PRESSURE SENSOR MODULE TO CONVERT THE MOBILE PHONES INTO DIVE COMPUTERS
}

\author{
${ }^{1}$ Miraç MEMIŞOĞLU, ${ }^{2}$ Tamer ÖZYİĞİT, ${ }^{3}$ Seçil ŞATIR, ${ }^{4}$ Salih Murat EGi \\ ${ }^{1}$ Bogazici Uluslararası Egitim Danismanlik Merkezi ve Tic Ltd, Kadıkoy, Istanbul, TURKEY \\ 2,4Galatasaray University, Computer Engineering Department, Ortakoy, Istanbul, TURKEY \\ ${ }^{3}$ FSMVU Mimarlik ve Tasarmm Fakültesi, Fatih, Istanbul, TURKEY \\ 11mirac@memisoglu.com, 2tozyigit@gsu.edu.tr, ${ }^{3}$ secilse@gmail.com, ${ }^{4}$ megi@gsu.edu.tr
}

(Geliş/Received: 08.05.2018; Kabul/Accepted in Revised Form: 04.11.2018)

\begin{abstract}
Diver carried computers are basically designed to measure the depth and time and provide safe ascent profiles in order to avoid decompression sickness in divers. All of the units in the market are based on embedded systems where the user cannot reprogram the units except entering limited number of dive parameters such as the content of cylinders and the conservatism of the computation.

An innovative system is designed and patented by the authors for implementing a diver carried computer using a mobile phone inside a pressure and waterproof housing in combination with an external microcontroller based electronic module. The aim of this work is to communicate the design of the key component of this system which is the external module built in order to measure pressure and temperature data and send them wirelessly to the mobile phone.

The external module compartment is placed adjacent to the mobile phone compartment. The impermeability is provided by two successive o-rings. A double lock system is used to prevent the external module and the mobile phone compartment from breaking apart underwater. The external module collects data from its sensors and peripherals and put them together into a so-called frame. This frame is transmitted to the mobile device using wireless communication (Wi-Fi or Bluetooth) and analyzed by the mobile device when received. This functionality is ensured by a minimalistic electronic design that includes a microprocessor, an oscillator, Wi-Fi module (IEEE 802.1x protocol) or Bluetooth, resistors and capacitors. The module is tested and benchmarked successfully with 7 existing dive computers in the market up to $42 \mathrm{~m}$ in open water conditions.

The system has the advantage of rapid model implementation and deployment, ability to run multimodel decompression procedures, user specific screen layout through the application of "skins", very large data logging capacity and all the advantages of mobile phones including sending post dive SMS messages in case of preset rules for emergencies, automatic wireless transfer of dive logs to research centers via internet and/or to dive center management services. Future projects target the use of photo and video recording, music and film playing capacities of mobile phones to entertain divers during long decompression stops as well. This platform is further expandable with additional modules to capture a wide variety of information such as oceanographic parameters like salinity, conductivity and dissolved oxygen.
\end{abstract}

Key Words: Bluetooth, Decompression sickness, Diver, Diving, SCUBA, Wi-Fi

\section{Akıllı Telefonları Dalış Bilgisayarına Dönüştürmek İçin Kablosuz Basınç Algılayıcı Modülü Geliştirilmesi}

ÖZ: Dalgıçların sualtında kullandığı dalış bilgisayarları, temel olarak derinlik ve zamanı ölçmek, dekompresyon hastalığını önlemek için güvenli çıkış profillerini hesaplamak için tasarlanmışlardır. 
Piyasadaki tüm cihazlar gömülü sistemler üzerine geliştirilmiştir ve kullanıcıya, tüpteki gaz, hesaplamaların güvenlik seviyesi gibi sınırlı dalış parametrelerini değiştirebilmek dışında yeniden programlama imkânı vermez.

Yazarlar, dalıcının sualtında su geçirmez bir kasa içinde beraberinde taşıyabileceği akıllı telefona bağlanarak ortam basınç ve sıcaklığını ölçen mikro denetleyici tabanlı bir modül geliştirerek yenilikçi bir sistem tasarlamış ve patentini almışlardır. Bu makalede, sistemin kilit bileşeni olan ve basınç ve sıcaklık verilerini akıllı cihaza ileten dış modülün tasarımı konu edilmiştir.

Dış modül bölmesi, akıllı telefon bölmesinin yanına yerleştirilmiştir. Su geçirmezlik iki ardışık conta (o-ring) ile sağlanmıştır. İkili bir kilit sistemi dış modül ve akıllı telefon bölmelerinin sualtında birbirlerinden ayrılmalarını engellemektedir. Dış modül algılayıcıları ve çevre birimleri sayesinde çerçeve olarak adlandırılan veri toplamakta ve bu bilgileri bir "yapı (frame)" içinde birleştirmektedir. Bu çerçeve kablosuz bağlantı (Wi-Fi veya Bluetooth) ile mobil cihaza gönderilmekte ve analiz edilmektedir. Bu işlev bir mikro işlemci, osilatör, Wi-Fi modülü (IEEE 802.1x protokolü) veya Bluetooth, dirençler ve kapasitörler ile sağlanmaktadır. Modül, açık denizde, 42 metre derinliğe kadar başarı ile test edilmiş ve pazardaki 7 dalış bilgisayarı ile karşılaştırılmıştır.

Sistemin avantajları, hızlı model uygulama ve kullanımı, çok modelli dekompresyon prosedürleri çalıştırabilme, kullanıcıya özel ekran tasarımları kullanabilme, akıllı telefonların avantajları ve SD kart olanağı ile büyük miktarda veri kaydı saklama kapasitesi ve dalış sonrası SMS gönderme, hazır acil durum kuralları, dalış kayırlarının araştırma merkezlerine ve/veya dalış merkezi yönetim birimlerine internet üzerinden otomatik gönderilmesi gibi akıllı telefonların tüm avantajlarından yararlanabilmesidir. Gelecek projeler, sualtında fotoğraf ve video çekme, uzun dekompresyon durakları sırasında dalıcının müzik dinleme ve film setretmesine olanak tanımayı içermektedir. Geliştirilen sistem ek modüller kullanılarak, tuzluluk, iletkenlik, çözünmüş oksijen gibi oşinografik parametrelerin ölçülmesi için kullanılabilir.

Anahtar Kelimeler: Bluetooth, Dalgıç, Dalış, Dekompresyon hastalığı, SCUBA, Wi-Fi

\section{INTRODUCTION}

Recreational SCUBA diving has become a mass leisure activity engaging millions of divers worldwide. The age of electronic has arrived with the development of the modern electronic dive computer as the most significant advancement in self-contained diving since the invention of the Aqualung by Jacques Cousteau. A dive computer is basically a submersible digital depth gauge that predicts a safe ascent in order to avoid Decompression Sickness (DCS). Decompression Sickness (DCS) is believed to be due to gas bubbles formed in the tissues and circulatory system after an excessive reduction in the ambient pressure (Elliott and Moon, 1993).

The first approach to avoid DCS was to tabulate "safe" decompression profiles in form of "Dive Table". The tables were designed basically for square depth-bottom time profiles followed by staged decompression or decompression with a fixed ratio. DCS is modeled and preventions on designing safe ascent schedules were designed as early as 1908 (Boycott et al., 1908). However, they need continuous improvements on safety even today (U.S. Navy Diving Manual, 2016). An example of US Navy Air Decompression Tables is given in Figure 1. 


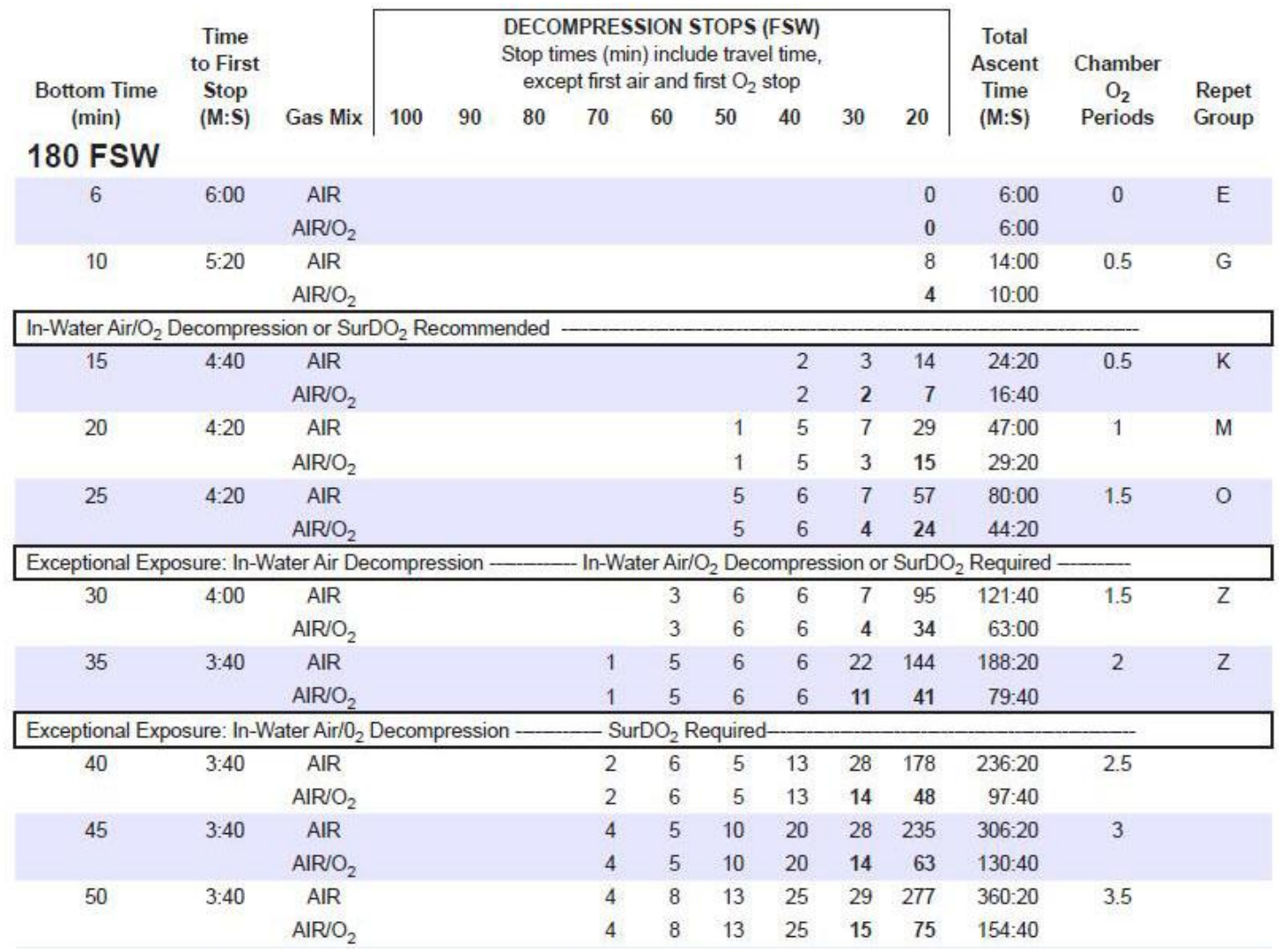

Figure 1. Dive Table for 180 feet (US Navy Diving Manual).

The use of tables is still valid for military and commercial diving areas; however, typical recreational diving xcursion involves multilevel and repetitive dives. The conservative use of dive tables was challenged firstly by nalog computers allowing the estimation of inert gas exchange at each dive depth and allowing more bottom time. hey were followed soon by digital dive computers. The most important advantage of these computers is that they ollect real-time pressure data and they theoretically calculate the amount of nitrogen dissolved in tissues according actual depth of diver. As the result, they are more effective than dive tables. Digital dive computer's function lay include measurement of tank pressure, ambient temperature, theoretical computation of acute oxygen oisoning as well (Azzopardi and Sayer, 2010). The photos of some modern dive computers are given in Figure 2.

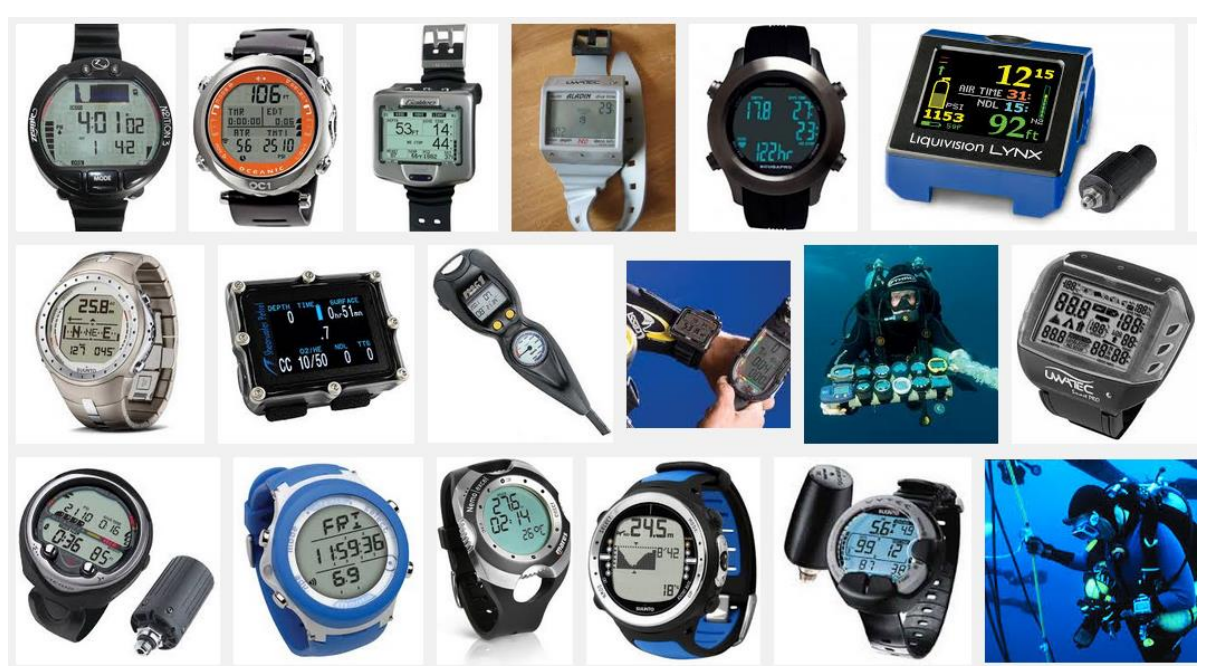

Figure 2. Examples of dive computers. 
On the other hand, all of the units in the market are based on embedded systems where the user does not have access to an operating system, and have limited programming options except entering limited number of dive parameters such as the content of cylinders and the conservatism of the computation, Consequently, actual dive computers can be defined as automatized gauges rather than "real computers" as their functions cannot be expanded and their algorithms cannot be assessed or altered according to different needs. Users have no possibility to use the data they store in computers for example with different algorithms and prepare post dive reports.

Research has been conducted to implement a diver carried computer using mobile phones protected in a pressure and waterproof housing (Dalış Bilgisayarı Tasarımı ve İmalatı; The Scientific and Technological Research Council of Turkey TÜBİTAK Project). Communicating wirelessly with an external microcontroller based electronic module equipped by sensors, the phone is able to collect data about ambient pressure and temperature. The decompression App developed for IOS and Android mobile phone can use these data to provide safe decompression profiles and some other useful information to divers (DepthMonitor App available at Google Play and iTunes). It can also benefit from mobile phone features in emergencies for sending automatic post dive messages, Global Positioning System (GPS) to mark dive locations and data storage capacity for dive logbook and photos. This system has been patented (Patent TR2009 02025B) and commercialized (Cep Telefonu ve PDA Tabanlı Dalış Bilgisayarlarının Üretim Altyapısının Geliştirilmesi ve Ticarileştirilmesi Projesi- Small and Medium Enterprises Development Organization of Turkish Science, Industry and technology Ministry) under the name "Divephone" as a groundbreaking alternative to dive computers. The aim of this work is to communicate the design of the key component of this system which is an external module built to send pressure and temperature data to the mobile device wirelessly.

\section{MATERIAL AND METHOD}

High frequency RF communication is not widely used in underwater applications. RF signals are attenuated to a great extent underwater. Therefore, the effectiveness of the signals is diminished. The following equation shows the changes of this attenuation;

$$
\alpha=0.0173 \sqrt{ }(\mathrm{f} \sigma) \mathrm{I}
$$

The equation where $\alpha$ is attenuation in $\mathrm{dB} /$ meter, $\mathrm{f}$ is frequency in hertz, shows that attenuation increases as frequency rises and finally $\sigma$ is conductivity in mhos/meter. This shows that low frequency transmission should be used for the underwater applications.

\section{Practical Approach}

In order to avoid the attenuation problem, two PDA devices are used to test the operation of short range Bluetooth and Wi-Fi transmission underwater. Two devices are put into the sealed boxes and file transfer over Bluetooth between two devices tried to be established. One of the devices is set as the sender whereas the other one is set as the receiver. First, two devices are located by 1-meter distance to each other. It is observed that no transfer could be established. When the distance set to less than $10 \mathrm{~cm}$, the transfer could be established. This distance depends on temperature and salinity as well. In Figure 3, photos of the experiments on Bluetooth transmission underwater are given. 


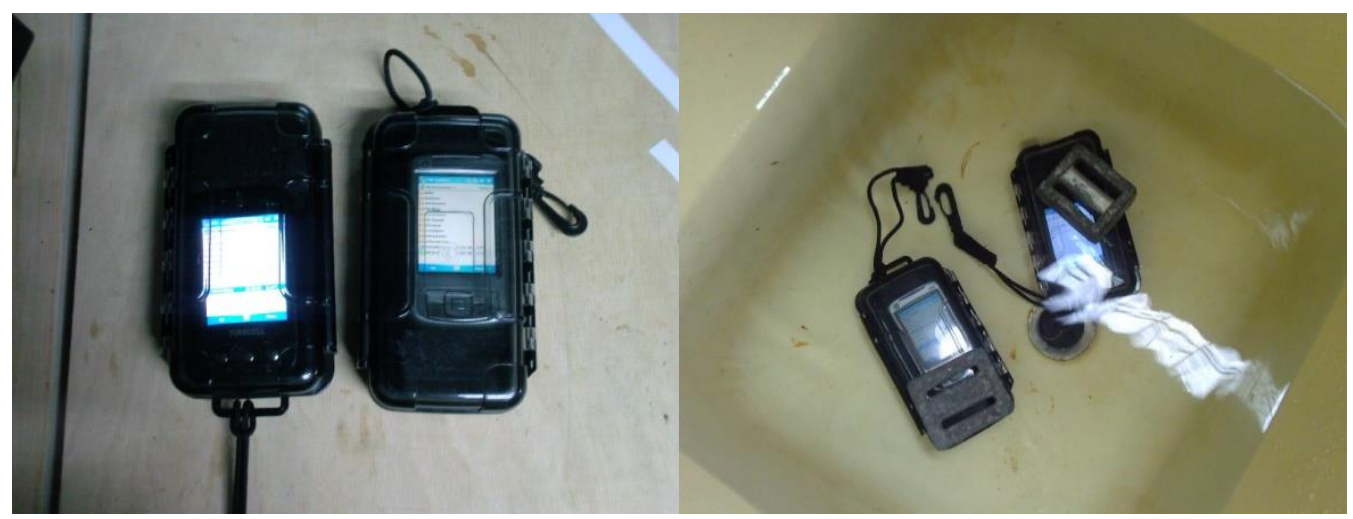

Figure 3. Experiments on Bluetooth transmission underwater.

Based on the results of the tests, it seems that reasonable to conclude that high frequency RF transmission underwater over a short distance is possible. There are two types of modules one of which is Wi-Fi to be used with iOS based mobile devices such as iPhone, iPod touch. The other one is Bluetooth to be used with Android based mobile devices.

\section{Mobile Phone Housing}

The housing is used to protect the mobile device from water under pressure and to carry the external module beside the mobile device. It has;

- Rectangular shape with $118 \times 61 \mathrm{~mm}$ internal dimensions

- The housing internal size is determined with respect to the iPhone 4/4S; thickness $+5 \mathrm{~mm}$, height $+2.5 \mathrm{~mm}$ which is $16 \mathrm{~mm}$.

- A transparent window topside of the dry compartment enabling the user to see the screen of the mobile device clearly

- A double lock cover system uniting the external module with the mobile device compartment

- A soft laying preventing the mobile device from being sketched and getting loose into the housing

- A ring (or a hole) to attach the system to the diver's gear

- Slots for strap enabling the diver to put the system on this arm

- Rated to $75 \mathrm{~m}$ (tested to $117.5 \mathrm{~m}$ )

The photo of the system's mobile phone housing is given is Figure 4 . 


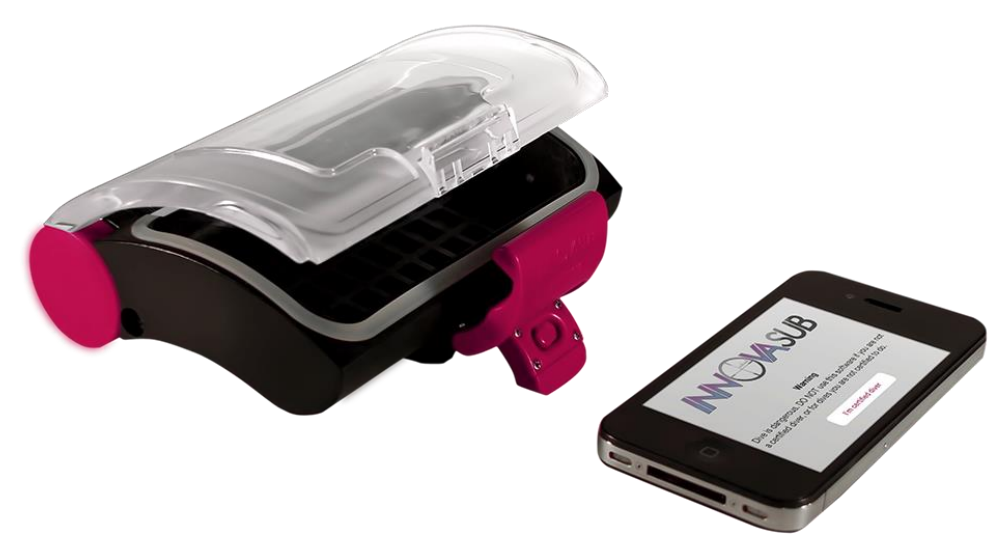

Figure 4. The housing of the mobile phone.

The housing's window for mobile device's screen is to be made by polycarbonate. It is mounted to the housing by multiple screws. The polycarbonate is demountable to be changed by a new one if broken. The user is able to see the mobile device's screen easily when the temperature measured between $0^{\circ} \mathrm{C}\left(32^{\circ} \mathrm{F}\right)$ and $60^{\circ} \mathrm{C}\left(140^{\circ} \mathrm{F}\right)$. The PDA compartment of the housing is sealed with o-ring and lock system. The closing system includes a secondary locking mechanism

\section{Wireless Module Design}

The main aim of the external module is to send dive data to the mobile device wirelessly. There are two types of modules one of which is Wi-Fi to be used with iOS based mobile devices such as iPhone, iPod touch. The other one is Bluetooth to be used with Android based mobile devices. As shown in Figure 5, the external module has,

- An independent housing/compartment rated to $75 \mathrm{~m}$ (tested to $117.5 \mathrm{~m}$ ), such that if it is flooded the housing of the mobile device will not be affected.

- $3 \times 5 \mathrm{~cm}$ dimensions

- Battery compartment with cover to allow the user the user for replacement of the battery 


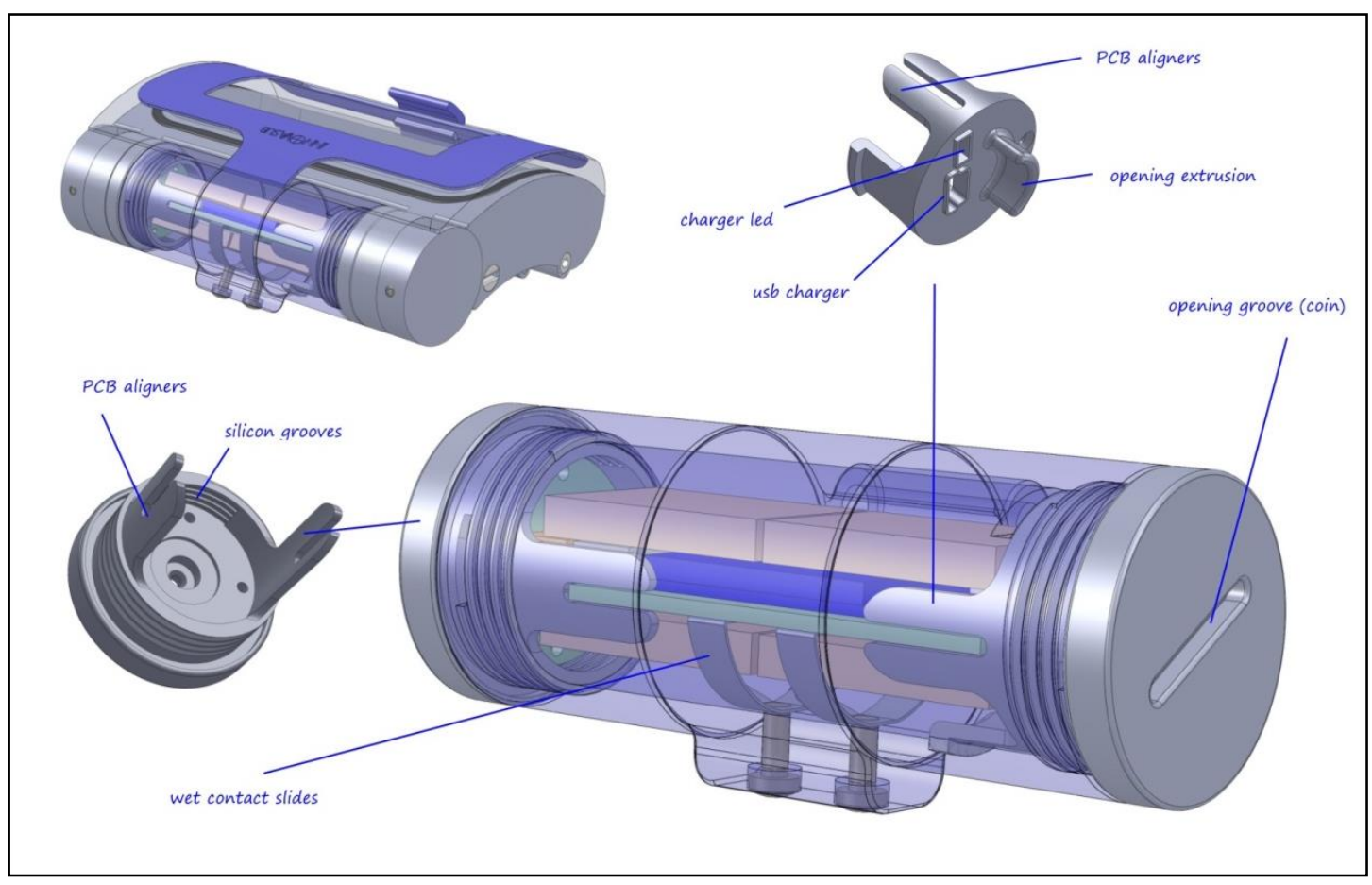

Figure 5. External module drawings.

On the PCB side which is electronic board development part, the module has following components,

- A microprocessor

- An oscillator

- Wi-Fi module (IEEE 802.1x protocol) or Bluetooth

- Resistors

- Capacitors

In addition to the mechanical and electronically parts, the following components are the parts soldered separately,

- An integrated pressure and temperature sensor

- Wet contacts

- Battery

The external module compartment is placed adjacent to the mobile phone compartment. The impermeability is provided by two successive o-rings. A double lock system is used to prevent the external module and the mobile phone compartment from breaking apart underwater. The lock system is designed not to get cause entanglement. The external module checks for the wet contact every 180 seconds. If the contact is cut, it returns to sleep mode after the next check. Upon wakeup, the external module shall begin to sense the pressure (depth), temperature and send the data by IEEE $802.1 x$ protocol to the mobile device. The external module's circuit design is given in Figure 6. 


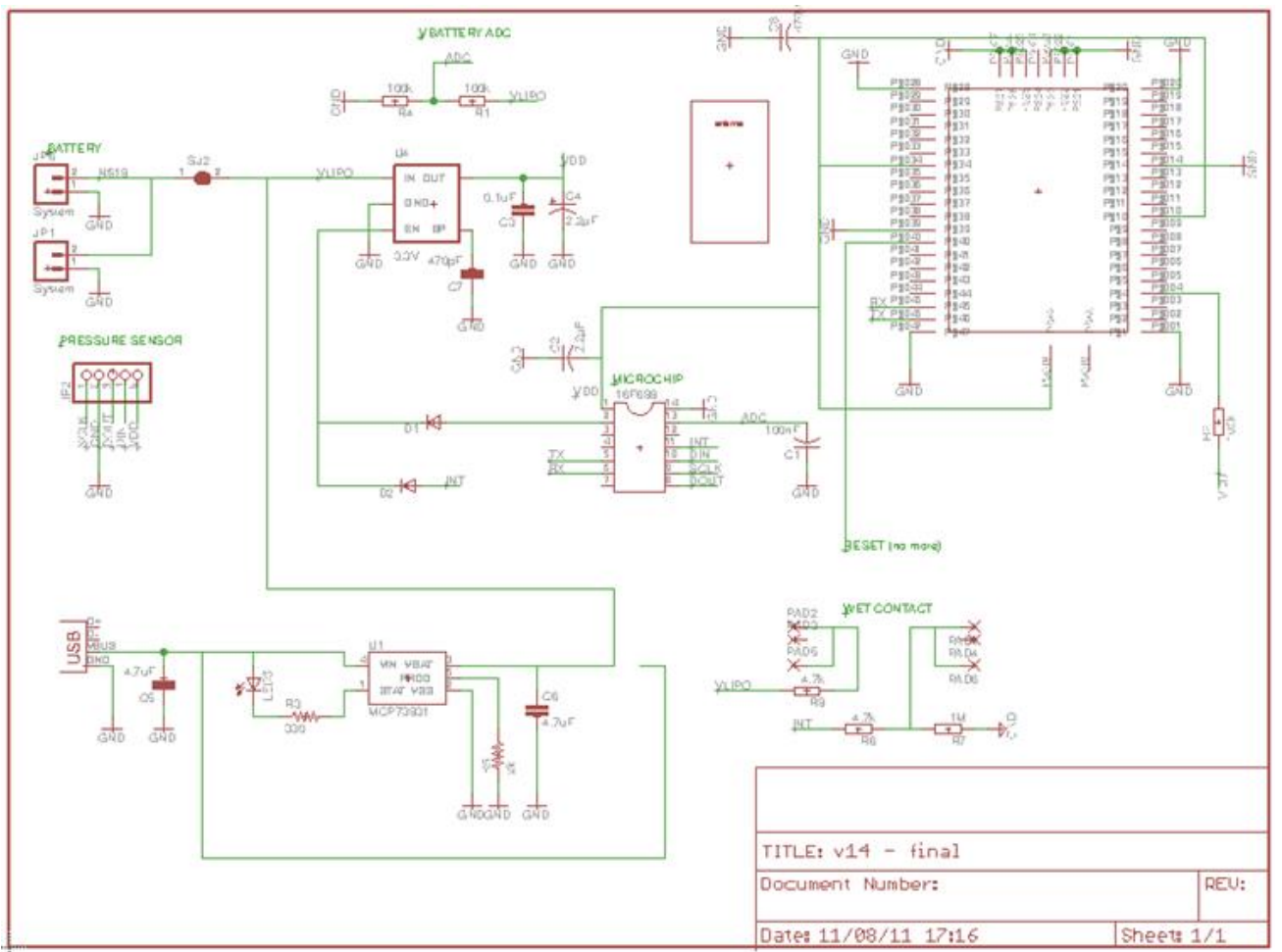

Figure 6. External module circuit design.

The battery compartment of the external module has no opening to the mobile device compartment so that the mobile device compartment is not affected in case of leaking. In addition to this, each module has a Serial Number, buried inside the cover of its housing.

\section{Communication Protocol and the External Module Firmware}

The purpose of the communication protocol between the external module and the cell- phone is to transmit the measures of the module to the mobile device with the best speed, reliability and safety of communication. The external module collects data from its sensors and peripherals and put them together into a so-called frame. This frame is transmitted to the mobile device using wireless communication (Wi-Fi or Bluetooth) and analyzed by the mobile device when received. A frame is made up with data collected by the module and some additional data in order to help the mobile device application to read the frame. In order to ensure that every data (frame) sent by the module will be properly received and read by the mobile device, the mobile device must send an acknowledge signal. This is a frame sent by the mobile device to inform the module a frame was properly received. If the module doesn't receive any acknowledge, it keeps sending the same frame to make sure the mobile device will receive it. Meanwhile, it stores the new frame to be sent into its flash memory (buffer) to send them later.

\section{Frames}

It would be wise to describe all the frames. Frame structure is the base idea of the mobile devicebased sensor development board. New frames can be specified and included into the monitoring system.

\section{Pressure sensor frame}

The pressure sensor frame contains the measures of the pressure sensor. Namely the pressure value (mbar) and the temperature. Time is the time the frame was generated by the module, in second. Time is 
an unsigned short that starts from 0 at the start-up of the module and counts the seconds. The maximum count of Time is 65535 . Temperature is coded as a signed Integer on two bytes (short). Its unit is $0.01{ }^{\circ} \mathrm{C}$. Its range is from $-327.68^{\circ} \mathrm{C}$ to $327.67 \circ \mathrm{C}$. The diagram of the pressor sensor frame is shown in Figure 7.

\begin{tabular}{|c|ccccccc|}
\hline Name & Header & Frame Head. & Frame Id. & Time & Temp. & Pres. & Cksm \\
\hline Type (size) & Char & Char & Short & Short & Short & Float & Char \\
\hline Size & 1 By. & 1 By. & 2 By. & 2By. & 2 By. & 4 By. & 1 By \\
\hline Value & '@' & 'P' & & & & & \\
\hline
\end{tabular}

Figure 7. Diagram of pressure sensor frame

Pressure is coded as a float (four bytes). Its unit is 1 bar and its precision is $0.00001 \mathrm{bar}=0.01 \mathrm{mbar}=$ $10 \mu$ bar. Its range is infinity. For instance, if the HEX value received is: "40 0893 9F", then its decimal float value is 2.13401 which makes 2.13401 bar.

Battery frame

The battery frame contains the ADC values of the Battery level acquisition and the of the $+3 \mathrm{~V} 3$ Line level acquisition. Time is the time the frame was generated by the module, in second. Time is an unsigned short that starts from 0 at the start-up of the module and counts the seconds. The maximum count of Time is 65535 . The diagram of the battery frame is shown in Figure 8.

\begin{tabular}{|c|ccccccc|}
\hline Name & Header & Frame Head. & Frame Id. & Time & BattADC & +3V3ADC & Cksm \\
\hline Type (size) & Char & Char & Short & Short & Short & Short & Char \\
\hline Size & 1 By. & 1 By. & 2 By. & 2By. & 2 By. & 2 By. & 1 By \\
\hline Value & '@' & 'B' & & & & & \\
\hline
\end{tabular}

Figure 8. Diagram of battery frame

BattADC is an unsigned short representing the ADC value of the acquisition of the battery level. $+3 \mathrm{~V} 3 \mathrm{ADC}$ is an unsigned short representing the ADC value of the acquisition of the $+3 \mathrm{~V} 3$ Line level.

Message frame

Time is the time the frame was generated by the module, in second. Time is an unsigned short that starts from 0 at the start-up of the module and counts the seconds. The diagram of the message frame is shown in Figure 9.

\begin{tabular}{|c|cccccc|}
\hline Name & Header & Frame Head. & Frame Id. & Time & Message & Cksm \\
\hline Type (size) & Char & Char & Short & Short & Char & Char \\
\hline Size & 1 By. & 1 By. & 2 By. & 2By. & 1 By. & 1 By \\
\hline Value & '@' & 'M' & & & & \\
\hline
\end{tabular}

Figure 9. Diagram of message frame

The maximum count of Time is 65535 which correspond to 43 days of running. Message is a char (1 byte) having a meaning. There are 256 different possible messages (see below). The diagram of the message definitions is shown in Figure 10. 


\begin{tabular}{|c|c|c|}
\hline Message & Value (decimal) & Description \\
\hline ERROR & 10 & Error, general meaning. \\
\hline $\begin{array}{c}\text { ERROR_PRESSURE } \\
\text { _SENSOR }\end{array}$ & 11 & $\begin{array}{c}\text { The pressure snesor does not deliver any value. } \\
\text { Communication with the sensor may be broken. } \\
\text { The Sensor will be Reset. }\end{array}$ \\
\hline BATTERYLOW & 254 & The battery level is low $(<3.3 \mathrm{~V})$ \\
\hline BOARD_SHUTDOWN & 255 & The module will soon shutdown \\
\hline
\end{tabular}

Figure 10. Diagram of some message definitions.

\section{RESULTS}

The Divephone basic module is tested and benchmarked successfully with 7 existing dive computers in the market up to $42 \mathrm{~m}$ in open water conditions and in dry chamber. Considering that one of the most critical concerns is the correct data collection form external module, the wireless communication between the modules and the mobile phone were tested and were proven to relay data without loss for Wi-fi and Bluetooth communication protocols. In Figure 11, a photo of the system used by a diver underwater is given. In Figure 16, another diver with the system is diving in İstanbul Aquarium.

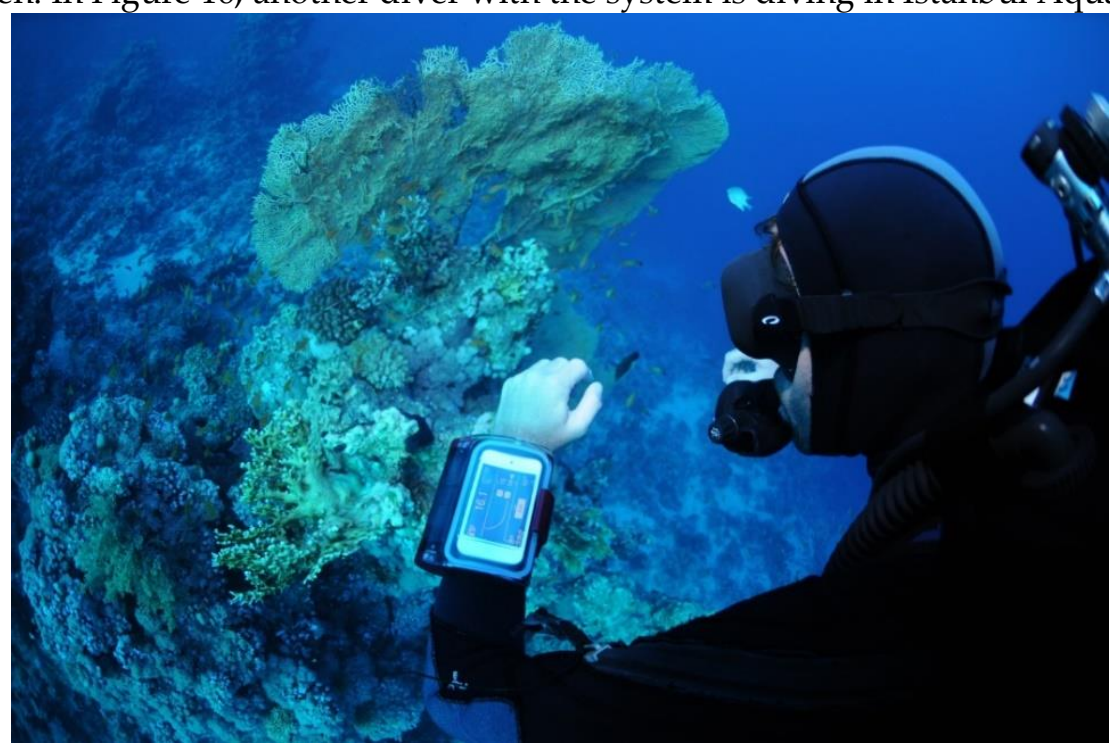

Figure 11. The system during a dive in Sharm el Sheik (Egypt)

The system's surface display, underwater display, display after entering decompression and a logged dive are shown in Figure 12, Figure 13, Figure 14 and Figure 15 respectively. 


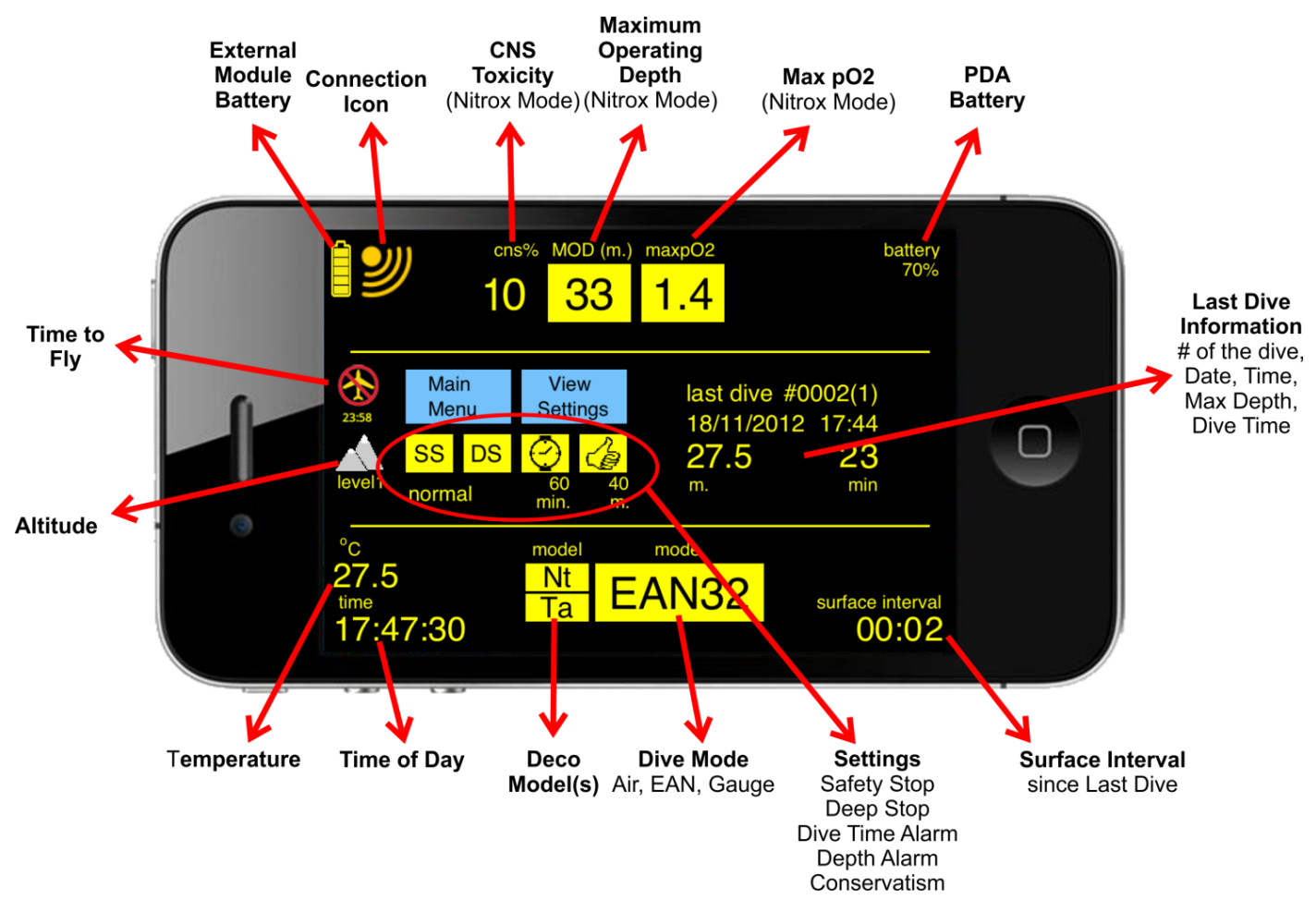

Figure 12. The system's surface display.

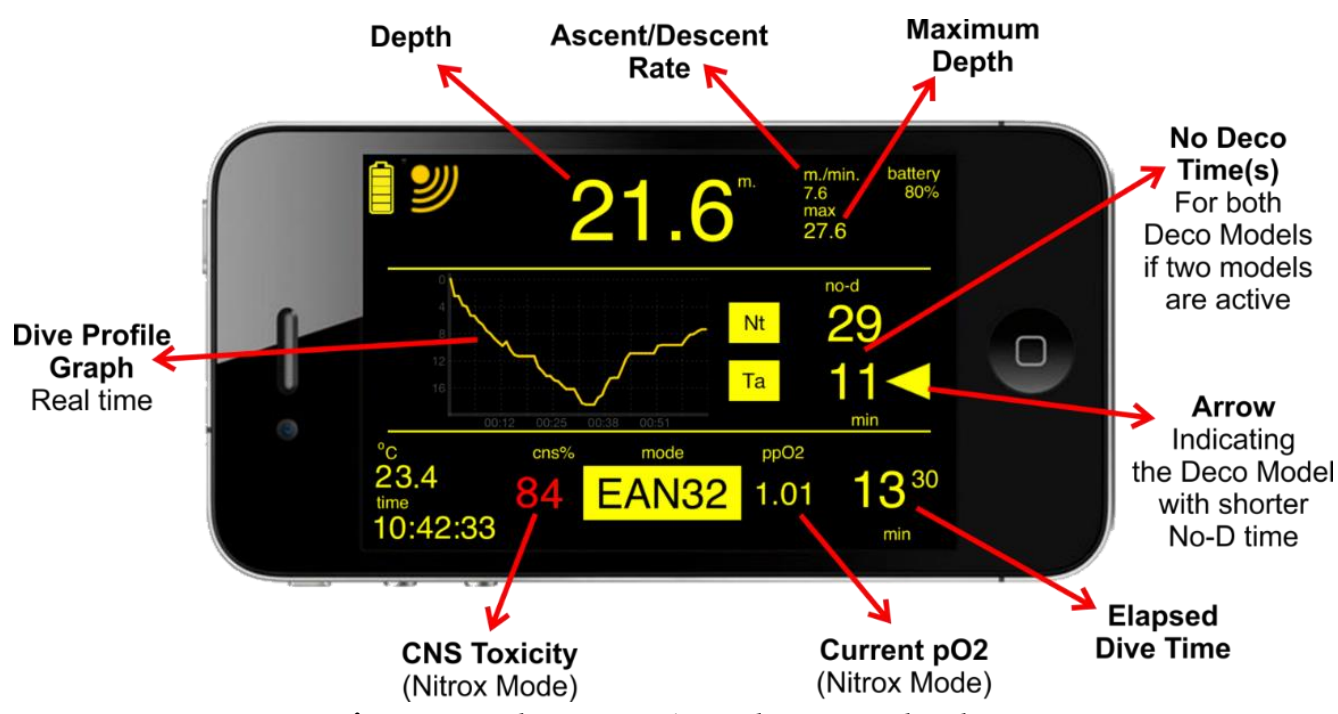

Figure 13. The system's underwater display. 


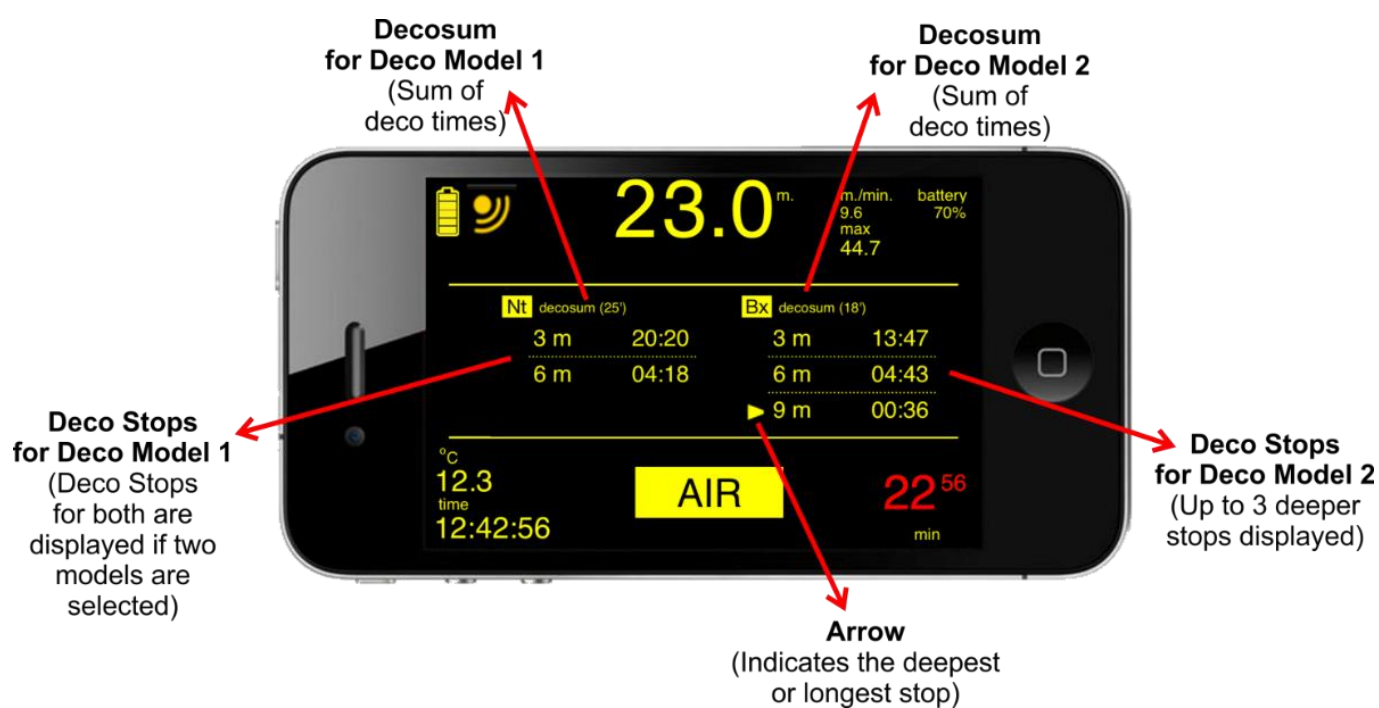

Figure 14. The display after entering to decompression.

\section{Dive Report [20130303-1602]}

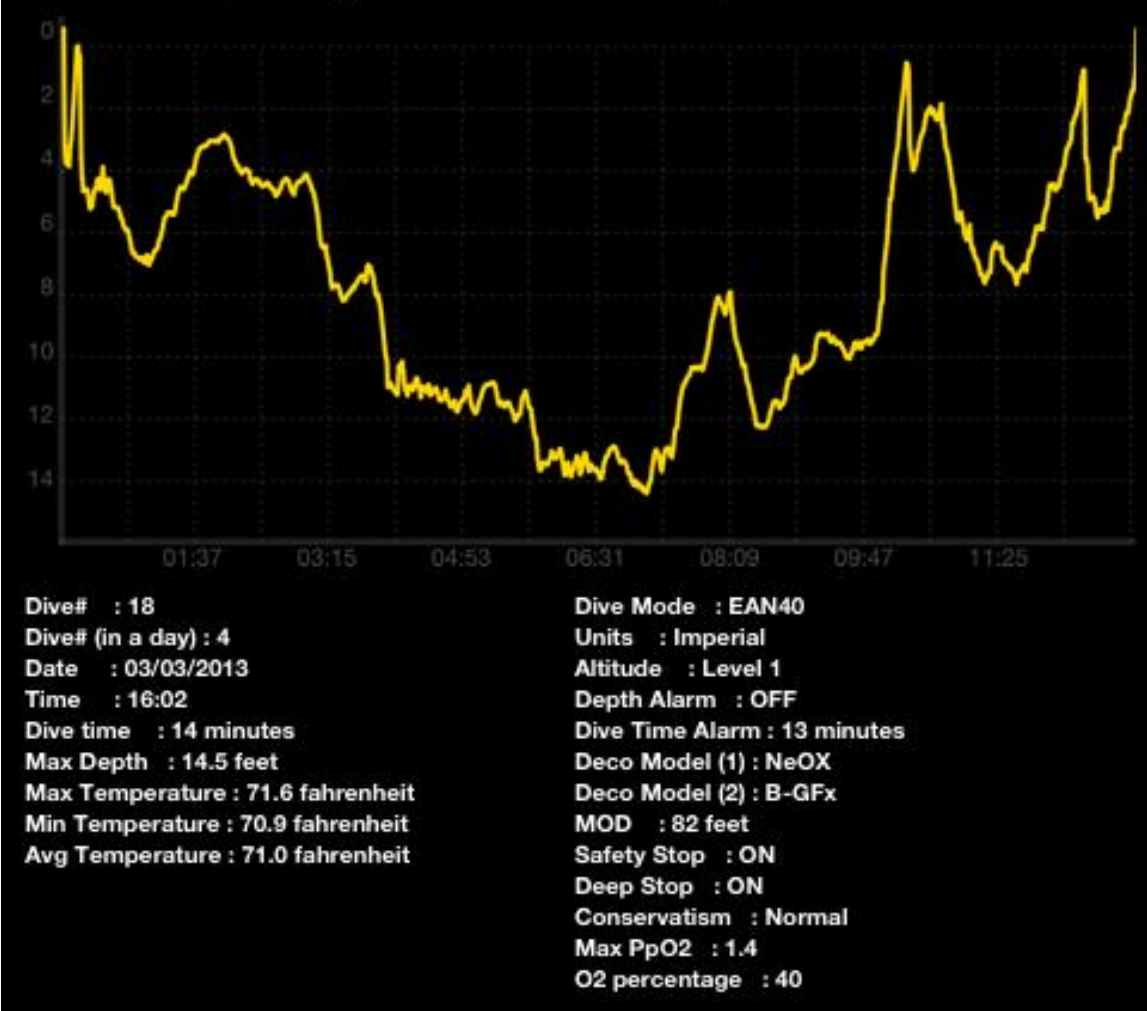

Figure 15. A logged dive sent by e-mail. 


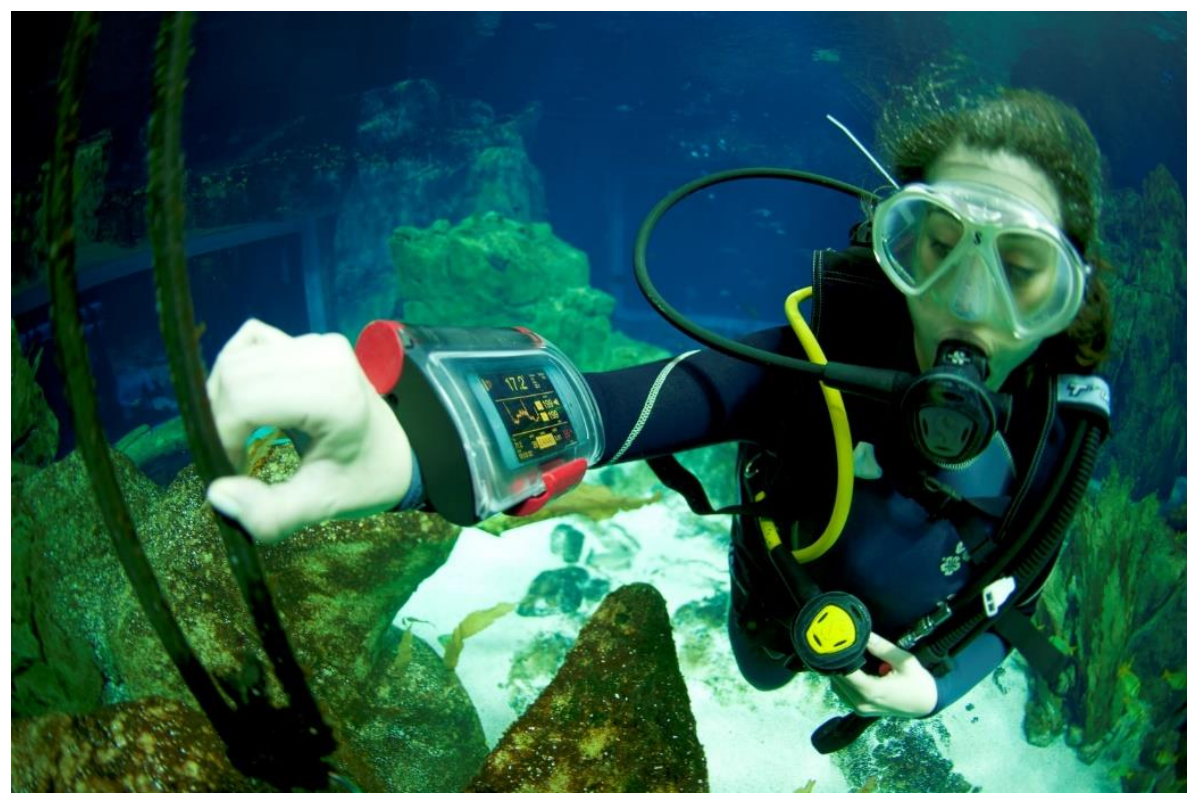

Figure 16. Divephone system underwater in İstanbul Aquarium.

\section{Algorithm Validation Tests Results}

The system, both pressure (and depth) measurement and application algorithm for providing a safe ascent schedule are tested by comparing with trusted dive computers widely used in diving community. One can found a variety of methods to algorithm validation (Huggins, 2006), (Lippmann, and Wellard 2004), (Blogg et al. 2004) and safety assessment (Sayer et al. 2016) of dive computers. For validating the Divephone system, we compared No-Deco limits and ascent schedules calculated by our system and various dive computers in markets. In Figure 17, an example for algorithm validation test form can be seen. In this for, the No-Deco Limits calculated by two decompression models of the system are compared with Suunto Vytec (Suunto - Vantaa, Finland) and Oceanic Veo (Oceanic Worldwide - San Leandro, California, United States). The No-Deco Limits calculated by both decompression models are consistent with the values calculated by the two different computers used as benchmarks. 


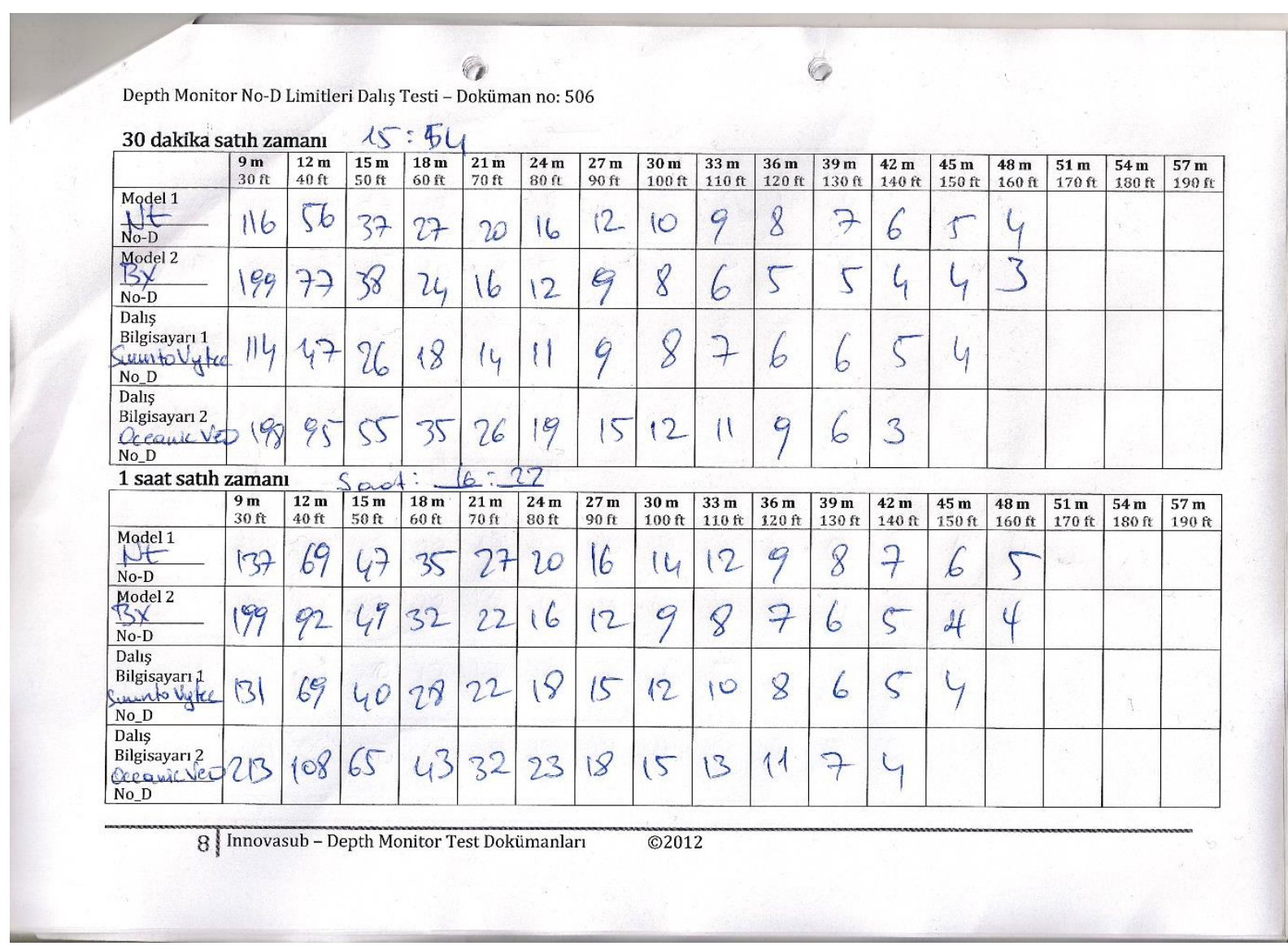

Figure 17. No-Deco Limits Test Form.

As the result, the system collects pressure and temperature data from external module and runs the decompression algorithms without any problem. Wide screens of PDAs inform the diver about current dive parameters and decompression plan effectively and the warnings are noticed easily.

\section{DISCUSSION}

Twenty-five years after modern day dive computer introduction, several key questions remain surrounding the decompression models used, validation and human testing, acceptable risk, limitations, failures, and operational reliability mainly due to the lack of cooperation between dive computer manufacturers and scientists (Lang and Brubakk, 2009). The system described in this communication offer a better platform for such cooperation. The system has many advantages against conventional dive computers. First of all, it is flexible as it allows rapid model implementation and deployment. The algorithms and user interface can be altered quickly with some programming adjustments. The system has the ability to run multi-model decompression procedures, user specific screen layout through the application of "skins", very large data logging capacity using external SD Cards and all the advantages of mobile phones including sending post dive SMS messages in case of preset rules for emergencies, automatic wireless transfer of dive logs to research centers via internet and/or to dive center management services.

Future projects target the use of photo and video recording, music and film playing capacities of mobile phones to entertain divers during long decompression stops as well. The platform is further expandable with additional modules to capture a wide variety of information such as oceanographic parameters like salinity, conductivity and dissolved oxygen. Consequently, it can be used not only for safety and comfort of divers but also as a convenient data collecting and processing device for underwater scientific studies. 


\section{ACKONOWLEDGEMENT}

Dalış Bilgisayarı Tasarımı ve İmalatı; The Scientific and Technological Research Council of Turkey TÜBİTAK Project.

Cep Telefonu ve PDA Tabanlı Dalış Bilgisayarlarının Üretim Altyapısının Geliştirilmesi ve Ticarileştirilmesi Projesi- Small and Medium Enterprises Development Organization of Turkish Science, Industry and technology Ministry.

\section{REFERENCES}

Azzopardi, E., Sayer, M.D.J., 2010. A review of the technical specifications of 47 models of diving decompression computer. International Journal of the Society for Underwater Technology, 29, 63-70.

Blogg, S. L., Michael, A. L., Møllerløkken, A., 2011. In: Proceedings of the Validation of Dive Computer Workshop. EUBS and Akademika Publishing. Ağustos 24. Gdansk, Poland, 128 p.

Boycott, A.E., Damant, G.C.C., Haldane, J.S 1908. The Prevention of Compressed-air Illness. Journal of Hygiene, 8, 342-443.

Cep Telefonu ve PDA Tabanlı Dalış Bilgisayarlarının Üretim Altyapısının Geliştirilmesi ve Ticarileştirilmesi Projesi- Small and Medium Enterprises Development Organization of Turkish Science, Industry and technology Ministry. Patent TR2009 02025B.

Dalış Bilgisayarı Tasarımı ve İmalatı. The Scientific and Technological Research Council of Turkey TÜBİTAK Project.

Elliott, D.H., Moon, R.H., 1993. Manifestations of the decompression disorders: The Physiology and Medicine of Diving. Peter Bennett and David Elliott, Eds., London, 481p.

Huggings, K.E., 2006. Evaluation of Dive Computer Options for Potential Use in $300 \mathrm{fsw}$ Heliox/Trimix Surface Supplied Scientific Diving. In: Advanced Scientific Diving Workshop; February 23-24; Smithsonian Institution, Washington DC, USA.

Lippmann, J., Wellard, M., 2004. Comparing Dive Computers. South Pacific Underwater Medicine Society (SPUMS) Journal, 34, 124-129.

Patent TR2009 02025B. Hardware, allowing pocket computers to establish wireless communication with sensors measuring various ambient conditions, diver and diving parameters, and a waterproof container thereof.

Sayer, M.D.J., Azzopardi, E., Sieber, A., 2016. User settings on dive computers: reliability in aiding conservative diving. Diving and Hyperbaric Medicine, 46, 98-110.

Symposium on Future of Diving-2009. 10 Years of Haldane and Beyond Location: Norwegian Univ Sci \& Technol, Baromed \& Evironm Physiol Grp. By: Lang, Michael A.; Angelini, Sergio (Editors: Lang, M.A.; Brubakk, A.O.). Trondheim, NORWAY, 128 p.

U.S. Navy Diving Manual, Rev7, SS521-AG-PRO-010, Naval Sea Systems Command, 01 December 2016, $2,63-86$. 